\title{
LIFE WITH SOVIET TROOPS IN CZECHOSLOVAKIA AND AFTER THEIR WITHDRAWAL
}

\author{
Prokop Tomek \\ Military History Institute Prague \\ Czech Republic \\ e-mail:prokop_t@yahoo.com
}

\begin{abstract}
The withdrawal of the Soviet Army from Czechoslovakia and dealing with its consequences has taken twenty-five years. Drawing mainly on archival sources, this contribution gives a short overview of the historical background, and the development and current situation of dealing with the difficult heritage of selected former military facilities. The foreign military presence deeply influenced the general attitude of the current Czech population towards foreign military presence. Among the many sites of Soviet military deployment, Milovice and Ralsko, discussed in this article, are distinctive examples, as they show both the opportunities for and limits of the recovery of former military sites.
\end{abstract}

Keywords: Czechoslovakia, military intervention 1968, Milovice, post-Soviet base, Ralsko, withdrawal

This paper is devoted to the Czech experience of the Soviet Army's over twenty years in Czechoslovakia and its consequences.

The Soviet occupation period of 1968-1991 represents an indisputably great trauma in the memory of the Czech society. Till now, Czech historiography has focused almost entirely on two key moments. The national resistance at the beginning of the occupation, in August 1968, has been celebrated as a moral victory and a time of national unity. The second event that has received considerable attention is the withdrawal of Soviet troops in 1991, which is likewise associated with liberation and victory (Macek et al. 1990 [1968]; Pecka 1996a). There is a general desire to forget about the time between these two moments because it is regarded as a period of weakness, progressive resignation, injustice, intimidation, and crime.

Research into the Soviet occupation years in the Czech Republic has been unsystematic, focusing almost entirely on the beginning and end of the Soviet military presence: 1968 and 1990-1991. At the beginning of the 1990s, the 
Institute of Contemporary History of the Czech Academy of Sciences carried out historical research on political, military, and historical aspects of the Soviet occupation. This undertaking resulted in the compilation of valuable documents. Several shorter studies dealt with casualties during the first months of the Soviet military presence in 1968 (Belda \& Benčík \& Pecka 1994a, 1994b, 1995; Benčík 1995; Benčík \& Pecka 1994; Benčík et al. 1995; Benčík \& Paulík \& Pecka 1999; Felcman 1995; Felcman \& Volková 1994). However, the period from 1968 till 1991 has hardly received scholarly attention, and only one postgraduate student in the last ten years appears to have chosen to examine the complete period of Soviet deployment in Czechoslovakia (Horák 2016). The main reason for this lack of interest has presumably been the scarcity of relevant open archival sources. There are also hardly any public sources (municipal chronicles, central and local media, etc.) that were not manipulated for propaganda purposes. But the reason could be partly due to Czech scholars' aversion to dealing with inconvenient and shameful aspects of their country's past.

This article, part of the research project "Czech society and the Soviet army 1968-1991", is based on a multi-year study of fatalities which occurred during the Soviet occupation that involved Soviet troops stationed in Czechoslovakia. I was able to access the documents of the plenipotentiary of the Czechoslovak government for temporary deployment of Soviet troops in Czechoslovakia, a valuable archival source that was made available only in 2012 . This material was used in a book focused on the description of fatalities and basic facts related to the Soviet military stay in Czechoslovakia (Tomek \& Pejčoch 2015).

While this study is primarily based on archival research, I have made two basic observational research trips to the Milovice area. On the first trip, I was there one day in September 2016, guided by a resident of Milovice, and I visited plenty of objects: ruins, reconstructed houses, and objects under repair. On the second trip, in May 2017, I was guided by a group of military heritage enthusiasts. Between my two visits, the ruins of at least two large objects were demolished: a large mess hall and an indoor swimming pool with remnants of special training equipment, including a pressure chamber and a facility for underwater rescue. I should also mention my actual first visit to Milovice. During the performance of my compulsory army service in 1986, I took a trip to the Soviet town of Milovice with my military unit as part of a friendship contact.

The research project "Czech society and the Soviet army 1968-1991" continues and includes other methods as well. Members of our team, sociologist Marie Černá and historian Michaela Tučková, have conducted several interviews with inhabitants in Milovice. The results of these interviews will be published during the next three years. 


\section{THE MILITARY INTERVENTION IN 1968 AS A STARTING POINT}

Soviet forces entered Czechoslovakia for the first time in 1944-1945, repelling the Germans, whose occupation had begun in 1939. Approximately 120,000 Soviet soldiers died during the liberation of Czechoslovakia from the German occupation. This fact, along with the general recognition of the Soviets' important role in the liberation of Czechoslovakia resulted in the local population's genuine sympathy for the Soviet Union and sense of gratitude. This mood prevailed not only in public discourse but was widespread among inhabitants of the country from May 1945 to August 1968.

The Warsaw Pact troops' intervention in Czechoslovakia in August 1968 is a well-known event (Czerwinski \& Piekalkiewicz 1972; Eidlin 1980; Skilling 1976). It has been estimated that more than 200,000 troops invaded Czechoslovakia from Germany, Poland, Hungary, and the Soviet Union. Approximately $90 \%$ of them were Soviet troops (Povolný 2010). Czechoslovakia was not prepared for such an attack (Fig. 1). The idea of putting up resistance to the Soviet Union, at that moment "the greatest friend and brother", was completely unacceptable to Czechoslovak political leaders. For twenty years the life of the whole country had been closely coordinated with the Soviet Union. But the reasons for non-resistance were political, ideological, and practical as well. Soviet partners were well informed about all the important facts needed to defend a country from foreign aggression. Yet, despite the lack of military

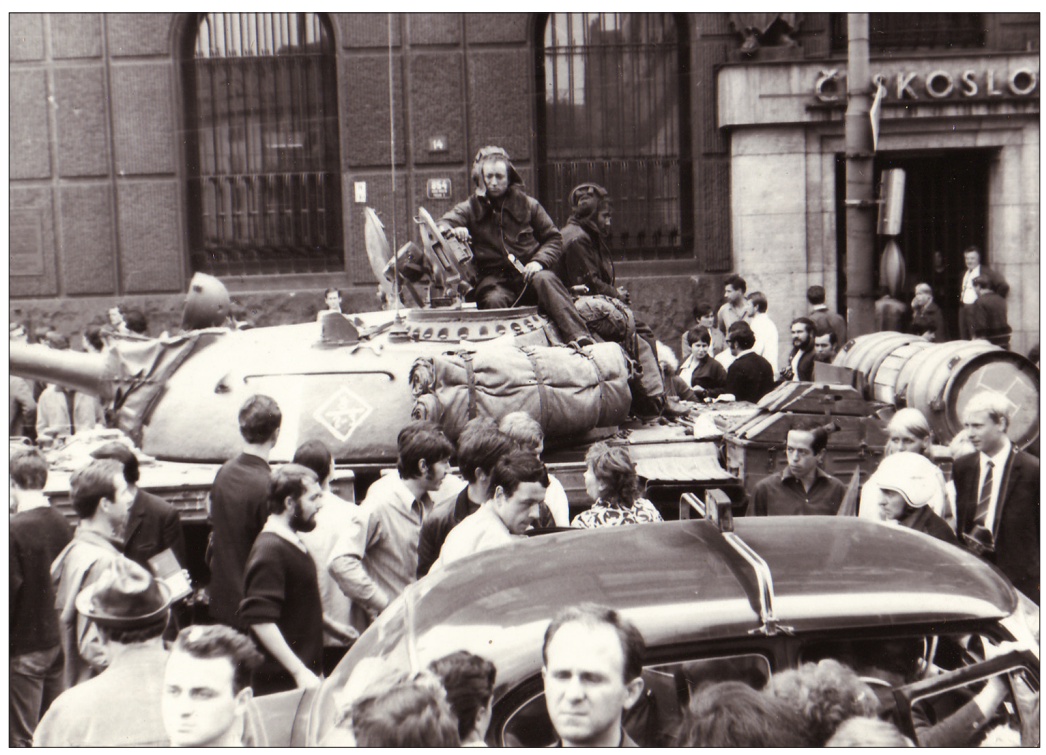

Figure 1. Soviet tanks in Prague, August 1968. Military History Institute Prague, 1968. 
resistance, the first months of the occupation of a defenseless country cost the lives of at least 135 Czechoslovak citizens, most of whom were arbitrarily shot or killed during many traffic accidents (Tomek \& Pejčoch 2015).

The reasons for the Soviet occupation of Czechoslovakia were not only the need to restore a Moscow-style political system and to maintain Czechoslovakia as a firm part of the camp of socialist states. Another important reason for intervention was to create an opportunity to deploy forces in Czechoslovakia as a southern part of the "Western Theater" of military operations in Europe. Soviet forces had been deployed in Czechoslovakia only from May to November 1945. Although Soviet soldiers committed many crimes during this short period of time, this fact did not change the overall picture of Soviets as liberators (Hubený 2013). After November 1945, Czechoslovakia was the only country in Eastern and Central Europe without Soviet military presence, if we do not count Soviet military advisers, of whom there were several hundred.

\section{CITIZENS' REACTIONS}

When discussing the Czech experience of Soviet occupation, it is important to look at changes in citizens' attitudes over time. In the first year after August 1968, almost $100 \%$ of inhabitants opposed the intervention, including those who up to the occupation had been deeply devoted to the Soviet Union. Czechoslovak politicians promised citizens that there would be a withdrawal of the Soviet troops after things had calmed down and that there would be a continuation of reforms (Tüma et al. 1996). Students comprised the most radical part of the society. They protested not only against foreign occupation but also against slowly rising defeatist moods among the general population. This period ended in August 1969, when security and armed forces violently crushed the first anniversary citizens' protests and the parliament quickly passed a law instituting severe penalties for disturbances of public order. Students called for the defense of citizens' rights. In November 1968, university students in Prague organized a huge work strike. In January 1969, a student, Jan Palach, sacrificed himself in an effort to lift people from their apathy and resignation. On January 16, 1969, in Wenceslaus Square in Prague, he suddenly poured petrol over his body and ignited himself. After three days of suffering, he died (Blažek et al. 2009: 39-89).

But citizens' attitudes deteriorated during the next couple of years. Party and society purges followed, in which the key question was: "What is your opinion of the Warsaw Pact intervention?" The politically correct answer was: "The entry of the armies was an act of fraternal help". Communist leaders gave a large part 
of the society, mainly blue-collar workers and representatives of the favored class, the opportunity to present themselves as having been confused at the time of the intervention, and to express regret for their former "wrong attitudes". Only "ideologically guilty" people, supporters of democratic reforms during the Prague Spring, and active opponents of the Warsaw Pact military intervention, were punished. Cadre purges were extensive: between 1968 and 1970, almost 500,000 people were expelled from the Communist Party of Czechoslovakia, which amounted to $30 \%$ of the members (Hradecká \& Koudelka 1998).

The majority of the population succumbed to passivity during the next couple of years, with many people taking advantage of purges and seizing vacant positions. How quickly peoples' opinion changed is illustrated by the fact that the decline in communist party membership ended in 1971. In 1988, the Communist Party of Czechoslovakia had 1.7 million members, meaning that $15.4 \%$ of the inhabitants of the country over eighteen years old belonged to the party (Hradecká \& Koudelka 1998).

Cadre purges affected not only party members, but everyone who had supported democratic reforms during the Prague Spring period of 1968. Active reform supporters were persecuted. They were fired or transferred to lower work positions. In a state with compulsory employment and the state as the sole employer, even second-rate jobs were difficult to find for these people.

The Soviet occupation had a heavy impact on national memory and morale. The massive intimidation of inhabitants resulted in the prevalence of passivity and defeatist moods. A part of the society, in fact, even after the Soviet intervention of 1968, could not forget two decades of devotion expressed to Soviet soldiers for the liberation of the country and the Soviet casualties in 1945 (Horák 2016: 49).

\section{HOW WERE THE SOVIET BASES IN CZECHOSLOVAKIA ESTABLISHED?}

Foreign military units taking part in the intervention left the cities and towns in autumn 1968. Most of them returned to their origin bases abroad. On October 16, 1968, the Soviet Union and Czechoslovakia signed a treaty for the temporary deployment of Soviet forces, according to which 75,000 troops were to be stationed in Czechoslovak territory. Soviet officers were accompanied by more than 30,000 family members. The name of the treaty was misleading, given that the date of withdrawal was left undetermined. A joke circulated by locals at the time captured the situation: Jaká je jednotka dočasnosti? Jeden furt (What is a unit of temporariness? It is one forever). 


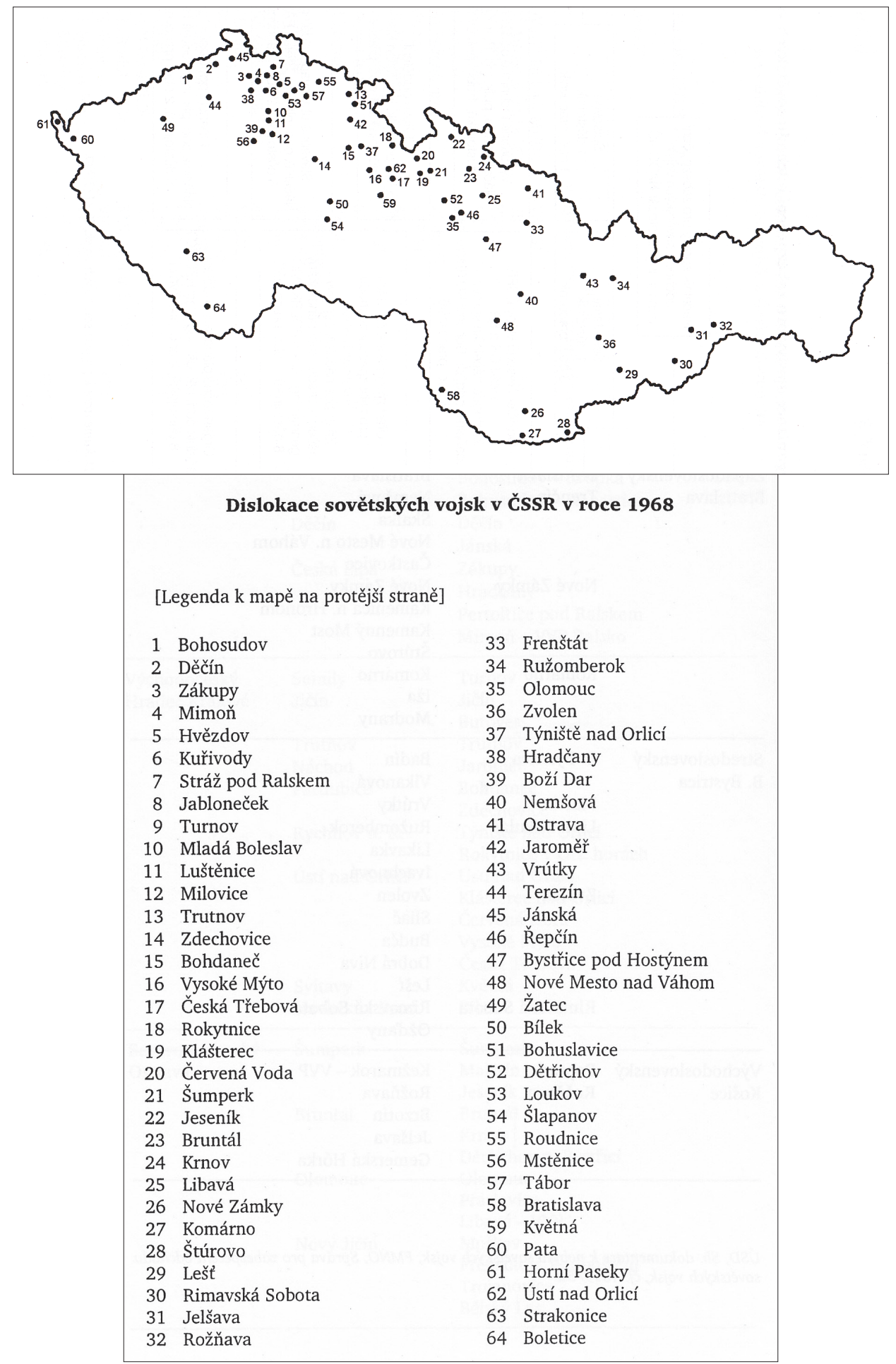

Figure 2-3. Central Group of Forces in Czechoslovakia (Pecka 1996a). 
At the beginning of the occupation in August, Soviet political leaders promised that troops would be withdrawn after securing the socialist system in Czechoslovakia. But very soon, in September and October 1968, it became clear that the Soviets wanted to deploy their troops in Czechoslovakia for at least a couple of years. Once a firm pro-Soviet regime had been established, nobody even raised the question of withdrawal.

The Central Group of Forces (CGF - the official name of the Soviet military contingent in Czechoslovakia) took over some of the military bases of the Czechoslovak Army. The latter had not created any of the zakrytie gorody (closed cities) found in the Soviet Union. And there were also no special apartment buildings within military bases, as was customary in Soviet garrisons. Most of the Soviet troops were deployed in the western and central parts of the republic, i.e. the Czech part of the Czechoslovak Republic, because it was closer to the enemy in the West. Only a small number of the forces were stationed in Slovakia. Altogether five army divisions and two air force divisions were deployed in Czechoslovakia. Compared with other countries of the Soviet bloc, the Central Group of Forces was about the same size as the South Group of Forces in Hungary. The Central Group of Forces was not so well equipped and was smaller than the Western Group of Forces in Germany (Nad'ovič et al. 2005).

For more than twenty years, Soviet forces were deployed on thirty-three bases, four airports, three military hospitals, six large storage areas, and five training areas (Pecka 1996a: 285-289) (Fig. 2 and 3). There were five army divisions. Two divisions were located in central and northern Bohemia, one division in eastern Bohemia and northern Moravia, one in northern Moravia, and the last division was deployed in Slovakia. The Group of Soviet Forces included one air division. Two airfields were located in northern and central Bohemia, one in northern Moravia and one in Slovakia.

Almost all Soviet military bases were located in small towns and villages. In Prague and Bratislava there were only small communication or liaison units. There were two headquarters: the main one in Milovice, to be discussed below, and the headquarters of the 28th Army Group in Olomouc.

\section{LIVING TOGETHER OR LIVING AUTONOMOUSLY}

The life of the Soviet Army personnel was hidden from the Czechoslovak public. It was contained almost entirely within the walls of military barracks and bases (Fig. 4). The rank-and-file troops could leave military barracks only in organized groups. As a rule, they did so for cultural purposes or for celebrations of political anniversaries, such as May 1 or the anniversary of the Great October Socialist Revolution on November 7. Soldiers also could leave military bases 


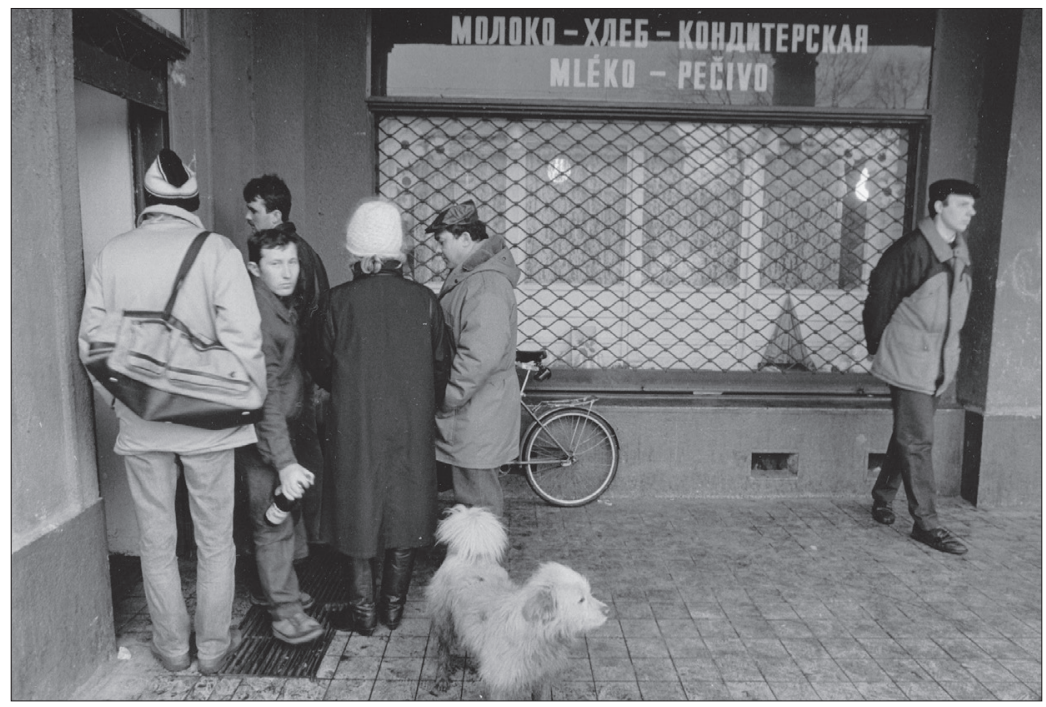

Figure 4. Everyday life of Soviets in Milovice in the late 1980s. Military History Institute Prague (photograph by Jan Jindra).

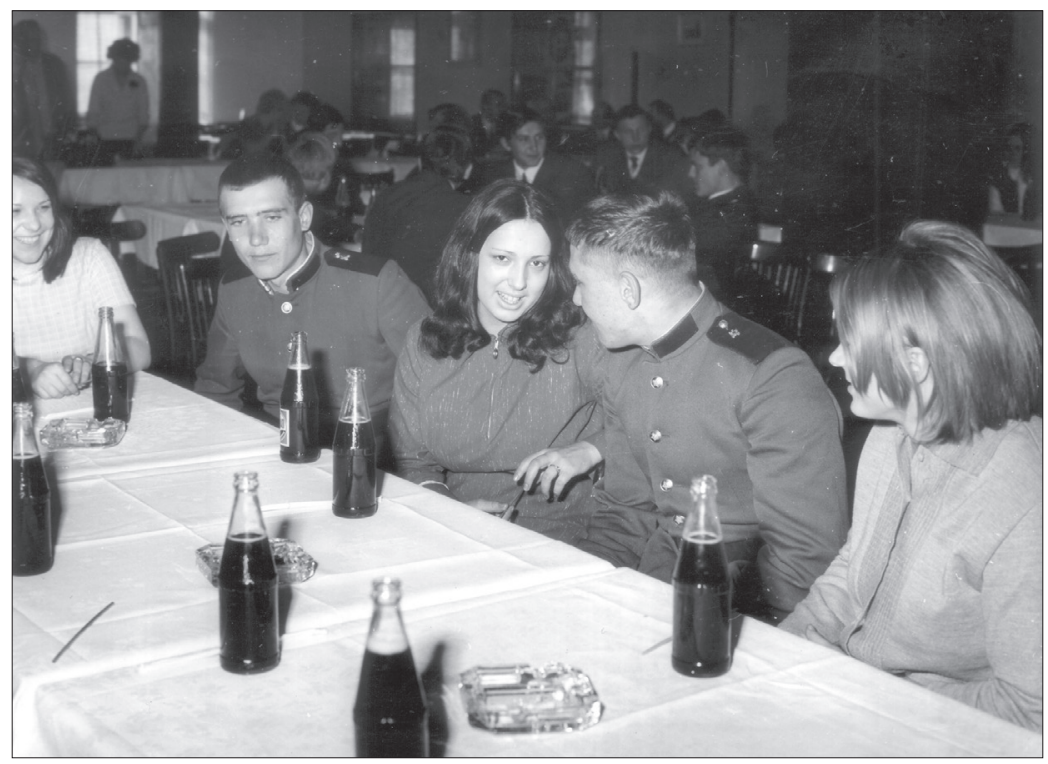

Figure 5. Arranged meeting of apprentices from the south Moravian region with Soviet rank-and-file troops in the 1970s. Military History Institute Prague. 
in order to provide help in construction, harvests or industry. These were occasions for meeting Czechs and Slovaks informally. Only officers and their family members could move about freely in shops, streets, and other public spaces. A small number of Czechs and Slovaks were employed at Soviet military bases.

Czechoslovak and Soviet forces lived and trained separately, meeting only in joint field exercises and organized visits (Fig. 5). No studies of this topic have been undertaken till now. Only a few isolated facts and testimonials are available (Tomek 2016). It is likely that joint activities were limited by concerns over personal conflicts between the two sides and their political consequences.

The contacts of Czechoslovak citizens with Soviet troops were limited. People usually had no desire to engage in genuine $d r u z h b a$ (friendship) with members of the Soviet military. However, taking part in official events offered a good opportunity to demonstrate favorable attitudes towards the regime. It could serve as a way of advancing individual careers and having more comfortable lives. Such organized events included meetings of young people (members of Komsomol and the Socialistic Youth Union ${ }^{1}$ ), celebrations of socialist anniversaries, and various cultural events. Such contacts were sometimes covered in the media. Ordinary people were forced to find a way to live next to Soviet troops.

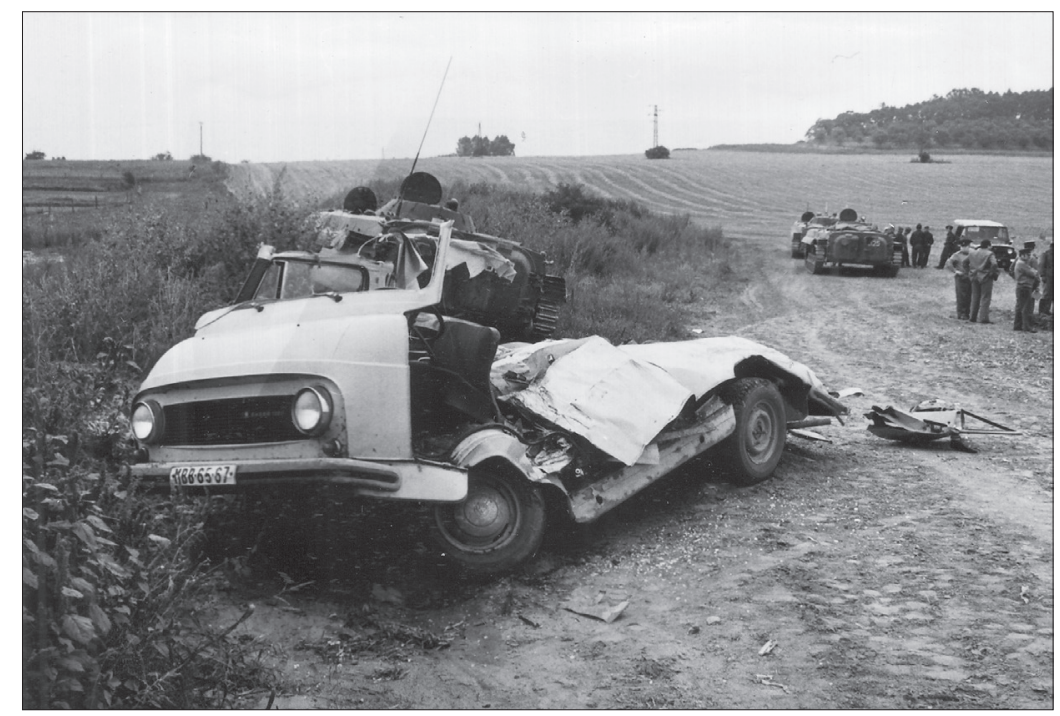

Figure 6. An example of the hundreds of more or less serious accidents caused by the Soviets. Military Historical Archive in Prague, 1982. 
Genuinely informal and vital relationships could emerge in the vicinity of Soviet military bases. These contacts were based almost entirely on "black market" needs. Some people took pity on rank-and-file soldiers during occasional informal contacts because of their poor life. On the other hand, there also were civilian victims of traffic accidents, murders, and rapes committed by Soviet soldiers or with their complicity (Fig. 6) (Tomek \& Pejčoch 2015: 78-96). During more than twenty years of the Soviet presence, there were 400 Czechoslovak citizens who died under such circumstances (ibid.: 357).

The long-term occupation gradually gave rise to a mood of hidden antipathy. Official media published nothing but positive news about visits, meetings, work assistance, cooperation, and joint military exercises (Pecka 1996b). Only exile organizations and newspapers abroad and the Charter 77 initiative $^{2}$ in Czechoslovakia protested against the Soviet military presence repeatedly. In August 1988, after twenty years of public silence, the first large demonstration took place in Prague. The reason for this public protest was the 20th anniversary of the Warsaw Pact's violent intervention in Czechoslovakia.

The withdrawal of Soviet troops from Czechoslovakia became a realistic option only after the Velvet Revolution of 1989. The demand for the withdrawal of Soviet troops from Czechoslovakia was one of the main topics on the agenda

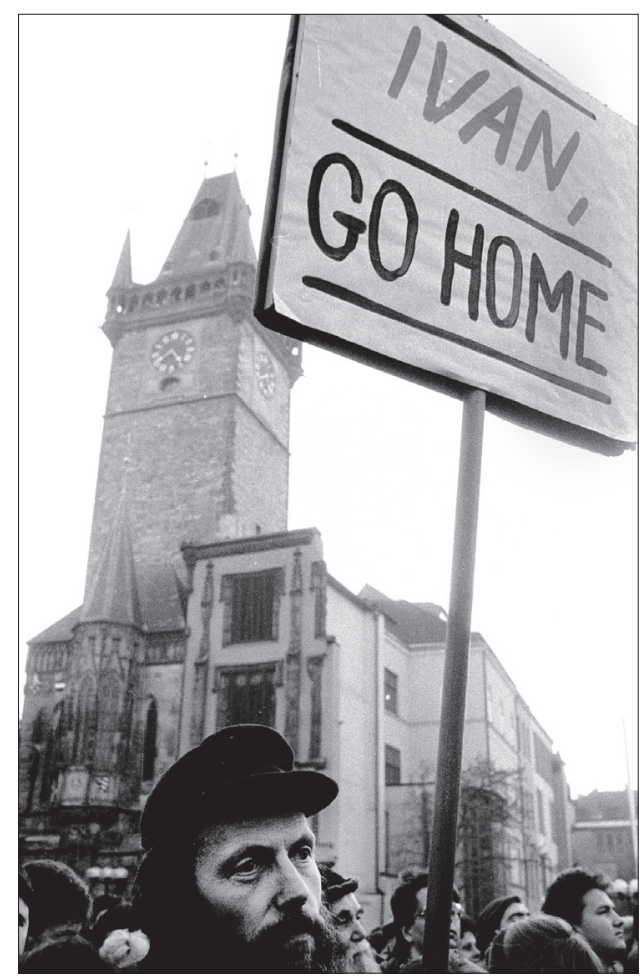
of the new democratic administration (Fig. 7).

Figure 7. Demonstration in Prague held to protest over the Soviet military presence in Czechoslovakia. Military History Institute Prague (photograph by Karel Cudlin 1990). 


\section{THE CONSEQUENCES OF WITHDRAWAL}

The exit of Soviet military forces from Czechoslovakia took one and a half years. By June 1991, all Soviet troops and their equipment were back in the Soviet Union (Pecka 1996a). The issue of the Soviet forces' withdrawal was one of the key topics during the Velvet Revolution in November and December 1989. The period of the withdrawal was relatively short due to favorable geopolitical conditions. The first session of Czechoslovak-Soviet talks took place in Prague in January 1990. At first the Soviet side attempted to prolong the presence of its forces in Czechoslovakia, referring to a lack of housing for officers' families and other social reasons, but finally accepted a deadline of June 1991. The second round of negotiations took place in Moscow the following month. On February 26, 1990, Jiři Dienstbier, a former dissident and at the time the Minister of Foreign Affairs, and Eduard Shevardnadze, the Minister of Foreign Affairs of the Soviet Union, signed a bilateral agreement in Moscow on the withdrawal of the Soviet forces from the Czechoslovak territory (Pecka 1996a).

The process of dealing with the consequences of the Soviet military presence has continued for the past twenty-five years. After the withdrawal, huge ecological damages were revealed, especially the contamination of soil in the areas used by the Soviet forces. The price of decontamination has amounted to more than one billion Czech crowns (thirty-six million euros). Demolition squads have spent years cleaning the large military training areas of Ralsko and Milovice. Dangerous ammunition was left not only in the ground but also in cesspits, sewage disposal plant tanks, boiler houses, and in deserted apartments (Pecka 1996a: 260-280). By 2001, in the Milovice area alone, around 185,000 rounds of ammunition had been found. These areas had to be cleaned before handing them over to civilians.

Former barracks and other real estate in military use could be utilized only partly. Neither the state administration nor local governments were prepared to deal with this property and with areas that had been devastated first by the Soviets, who took all of the useful items during the withdrawal because of a lack of building materials and furnishings in the Soviet Union, and subsequently by Czech metal thieves. There was no privatization law at all.

The small Czechoslovak state, which in 1993 was divided into the Czech Republic and the Slovak Republic, had also come to terms with its own military heritage: 200,000 Czechoslovak troops and their equipment had to be drastically reduced during the $1990 \mathrm{~s}$.

Some former military compounds have been rebuilt only partially. As a rule, it has been easier to use former military barracks located on the fringes or within cities. Such complexes have been successfully turned into apartments, 
schools, hospitals, administrative offices, homes for the elderly, and shops. For example, the historical city of Olomouc in north Moravia housed the headquarters of the 28th Army Corps of the CGF during the occupation. Now the University of Olomouc's administration uses more than 600 reconstructed apartments as students' dormitories and the local administration is using other apartments to house citizens. The city administration in Olomouc took over a military airfield, formerly the base of the 490th Helicopter Regiment, which now serves many civil aeronautical purposes. In the town of Mladá Boleslav, the 18th Guards Motorized Rifle Division was located. Its barracks now serve as the town hospital and are used to house pensioners and others in need of housing (see Mladá Boleslav).

\section{POST-SOVIET MILITARY ZONES: MILOVICE}

Civilian utilization of large military zones lying outside towns and cities has posed greater problems. One example of this is Milovice, located forty kilometers north-east of Prague. The military history of this region is quite long. In 1904 an artillery range of the Austro-Hungarian Army was established in this area. This training facility was at the time the most important military site in the Czech part of the monarchy. Milovice at that time was a small village, with around 1,000 inhabitants. After 1918 the new Czechoslovak Army took over the training area and during World War II it was used by the Wehrmacht. After the war, the Czechoslovak Army returned. With the exception of the Wehrmacht, all of these users were able to coexist with the civilians in the area. The Wehrmacht displaced dozens of villages for the purpose of creating a bigger military training area. Another chapter of military-civilian coexistence was opened in 1968 (Blahová 2016).

Soviet forces were deployed in Milovice for the first time from May to November 1945, after the liberation of Czechoslovakia from Nazi occupation. This fact was probably one reason why Soviet forces coming to Czechoslovakia in August 1968 very soon tried to achieve control over Milovice. Its long distance from big cities and existing military facilities promised to make it a perfect site for the most important units of Soviet forces in Czechoslovakia. On the fringes of the existing town of Milovice a Soviet military city was established, which served as the headquarters of the whole Central Group of Forces (Fig. 8). After the withdrawal of Soviet forces, thousands of apartments, a cultural center, sports fields, swimming pools, a hospital, shops, an elementary school, military training facilities, and a number of other buildings and establishments were 


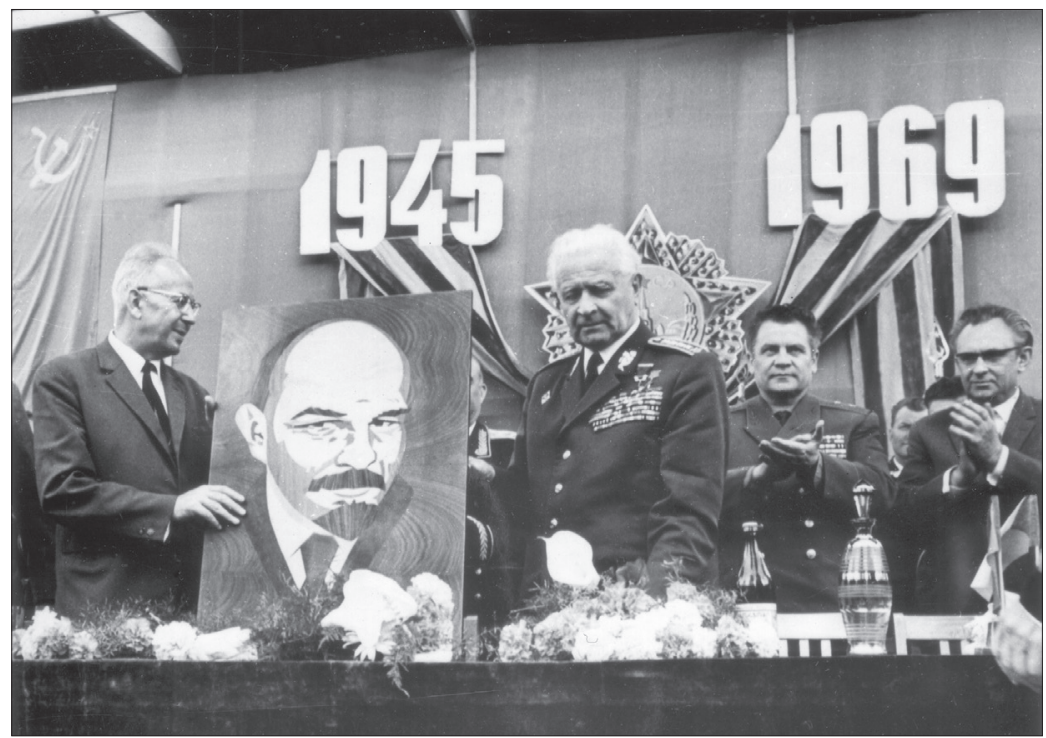

Figure 8. The first visit of political and state leadership in Soviet Milovice. Military History Institute Prague, 1969.

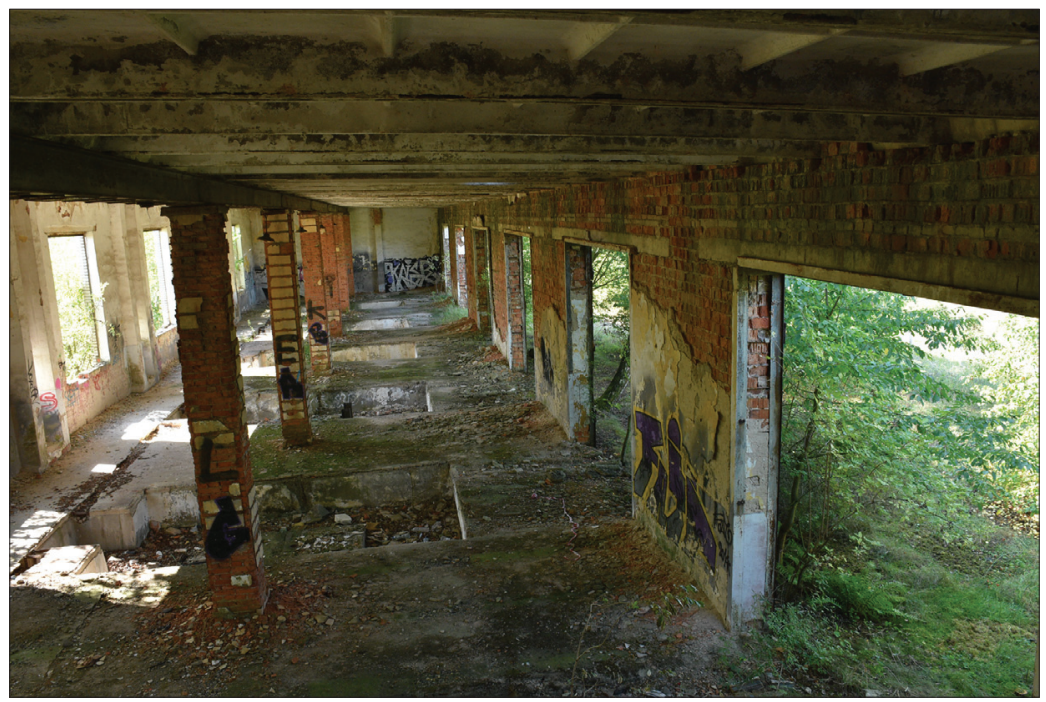

Figure 9. The town of Milovice at present. Photograph by Prokop Tomek 2016. 


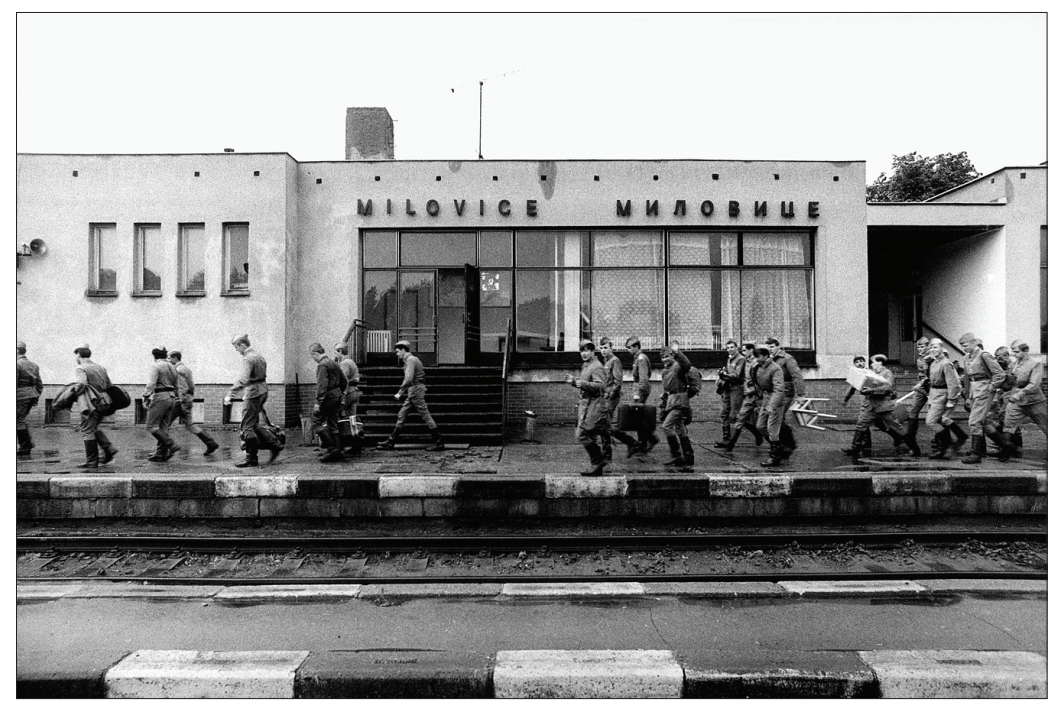

Figure 10. The withdrawal of Soviet forces from Milovice. Milovice railway station. Military History Institute Prague (photograph by Karel Cudlín 1991).

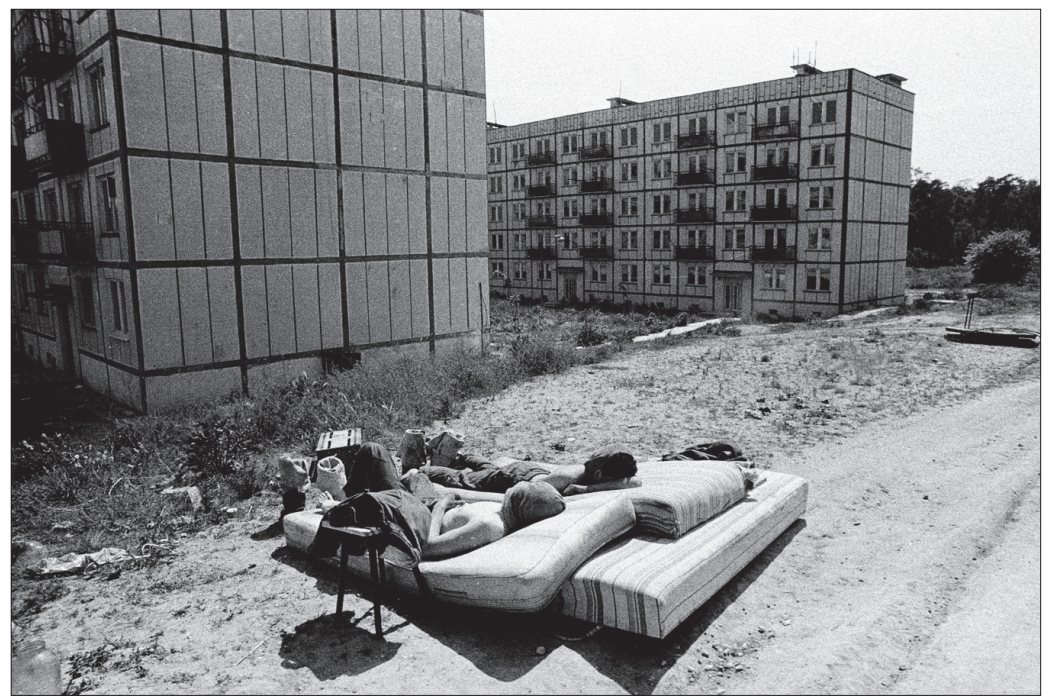

Figure 11. Concrete buildings in Milovice after the withdrawal of Soviet forces in the 1990s. Military History Institute in Prague (photograph by Karel Cudlin). 


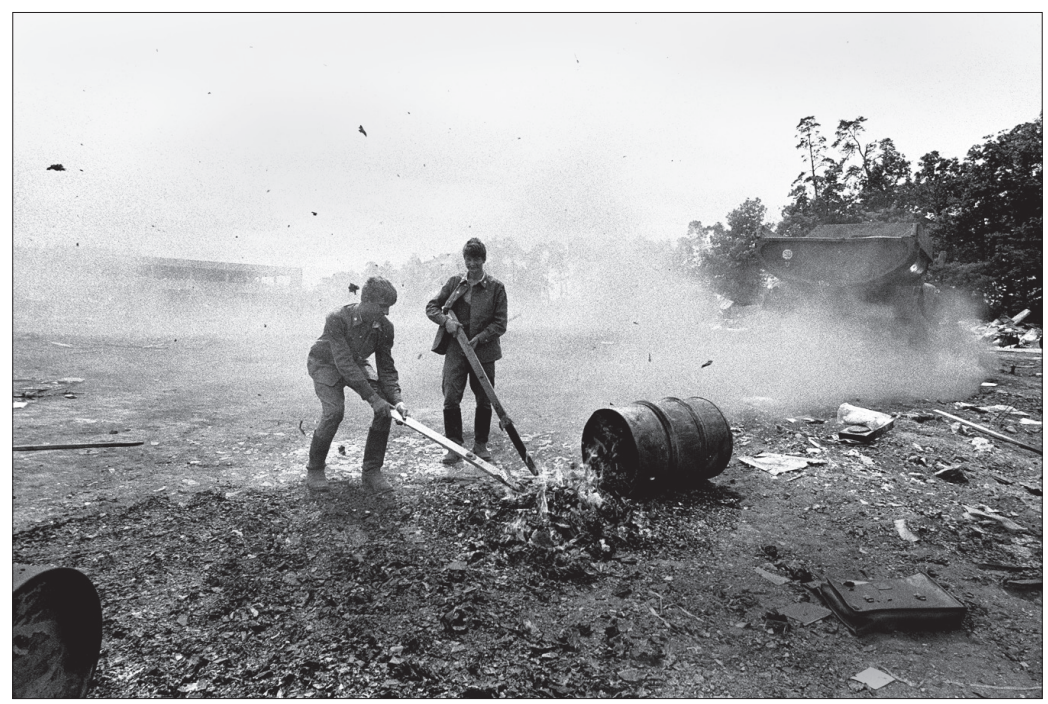

Figure 12. The general situation around military objects left by the Soviet Army in the 1990s. Military History Institute Prague (photograph by Karel Cudlin).

abandoned in the huge former military area. The majority of these facilities were seriously damaged during the past two decades (Fig. 9). Yet only one part of the area, a housing project of Soviet concrete apartment buildings in the area of Milovice-Boží Dar, near an airfield, was demolished.

The population of Milovice shrank after the withdrawal in 1991 to 1,200 inhabitants, almost all of whom had been living in Milovice since before the Soviet occupation (Fig. 10). The withdrawal was a great shock to the whole area (Figs. 11 and 12). Only a couple of months earlier, Milovice had been a town of about 50,000 inhabitants. In addition to Soviet civilians and soldiers, there were the Czech inhabitants of the old village of Milovice. Some local sources say that

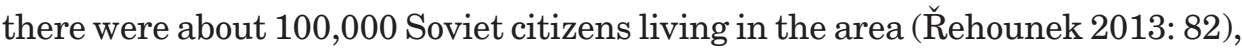
yet this is unrealistic, because this figure would have been $90 \%$ of all the Soviet soldiers and their families in Czechoslovakia. In 1990-1991, Milovice changed into a village with an abnormal heritage of property characteristic of a deserted town. It quickly became a target of metal thieves. In the surrounding forests and in ruins plenty of illegal or semi-legal activities took place, for example, rave parties, car club meetings, paintball and airsoft games, urban explorations, and techno parties, especially in the 1990s (Pohunek 2015). Some of them, for example, music festivals and military exercises, were held legally though. 
The first to settle in Milovice over the next two years were 120 immigrants from Ukraine. These people were ethnic Czech settlers from Volhynia (in the Chernobyl area), who had requested repatriation to the Czech Republic after 1989. In the course of the next two decades, the local administration succeeded in reconstructing the devastated apartments, while also launching the construction of new housing by real estate developers. More recently, Milovice has started a project to put the former Soviet airfield of Boží Dar into commercial use. Formerly there had been speculation about constructing a huge international

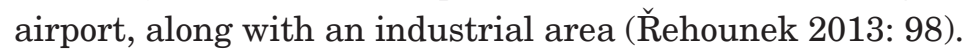

In 1991 the state proclaimed Milovice a town. Revitalization of the Milovice area is still going on today. At first, there was a lack of schools and social infrastructure. There has never been a big local employer. In 2003 unemployment reached $12.5 \%$. By 2015 , it had dropped to $6.6 \%$. There were new job opportunities in developing private enterprises in Milovice but the main reason for the falling unemployment rate was an improved connection to Prague. The railway to Prague was reconstructed at the beginning of the new millennium. In 2010 direct city trains started operating between Milovice and Prague, reducing the travel time to forty-five minutes or less. About 12,000 permanent inhabitants live in Milovice today, while approximately 2,000 more are renting temporary accommodation. There are two basic schools and four kindergartens (Město Milovice).

There was no other way to attract people to Milovice except to offer them cheap housing in a rapidly developing region that is quiet and close to nature. Over 10,000 people have moved there during the last twenty years, including many young people. Milovice's population probably has the lowest average age of any municipality in the Czech Republic. The average age of residents is thirty-five years, while the national average is forty-two years (ibid.).

How are the new settlers preserving the memory of the locality? The pupils of the basic school in Milovice have rediscovered and designated the site of the nearby village of Mladá, which was wiped out in 1904, at the time of the establishment of the first Austro-Hungarian military training area. Pupils placed information panels in the forest to commemorate the 100th anniversary of this event (Milovice). References to the Soviet past, however, are almost nonexistent. There are no marked tourist paths in the town, and no information panels presenting the past of the site. The town's website mentions only one historical site of interest regarding the Soviet past. In the town hall, the former Dom Officerov (Officers' House), there is a mosaic entitled Bojové družby se sovětskými vojsky ('The combat friendship with the Soviet forces'), which was made in the 1980s as a Czech gift to the Soviet Army, and it consists of 440,000 tesserae. It is allegedly the largest mosaic in central Europe (Milovice). 
In Milovice it is possible to see conserved architecture of the "Austrian camp": brick houses erected at the time of the Austro-Hungarian monarchy. This part of the town has remained surprisingly intact since its construction over 100 years ago and has developed a nice park-like character. The German Nazi occupation period, on the other hand, influenced the town's architecture only minimally, though the Wehrmacht destroyed some villages in the surrounding area in the course of its tactical military training activities during World War II. The Czechoslovak Army restored its presence and activities in Milovice in 1946, but during the first months of the Warsaw Pact occupation in 1968 the Soviet military leadership expressed an interest in Milovice. The reasons included good experience from the short Soviet stay in Milovice after the 1945 liberation, the town's unique isolated location, its huge airfield and the possibility of expansion.

Enterprises in today's Milovice focus more on the present or future than the past. A former training ground for tanks has been turned into an amusement and educational park called Mirakulum Park. Next to it is Tankodrom, a former tank training area where one can now ride heavy equipment through wasteland. One former Soviet building located at the edge of the large artillery range, used originally for military training purposes, has been rebuilt as a special ski simulator, unique in the Czech Republic. A safari park was opened in the target area of the artillery range: there are forty hectares of wild steppe with the remains of Wehrmacht observation bunkers. Herds of wild horses, aurochs and European bison have recently found a home in the safari park. The town administration wants to bring in more tourists. New wooden observation towers are rising at the edge of the safari park. These initiatives are being carried out by the nongovernmental organization Česká krajina (Czech Landscape) with funds from the European Union and various other parties (Česká krajina). It follows from these developments that nature and amusement will be the main attractions in Milovice, while the past receives little or no attention.

All in all, Milovice is a remarkable town. Great progress has been made in the integration of the region into the civilian world, though there still are some empty areas.

\section{POST-SOVIET MILITARY ZONES: RALSKO}

A completely different story can be told about Ralsko in the north of the Czech Republic, another former Soviet military zone. Ralsko was the site of another Soviet airfield, Hradčany, and of a military training area. An extensive bomb disposal project, lasting ten years, was undertaken in Ralsko after the Soviet 
withdrawal. The airfield with underground shelters for soldiers has been used only sporadically, mostly for the filming of war movies, including the films "Stalingrad" (1993), "Dark Blue World" (2001), and "Child 44" (2015). Rows of completely devastated concrete apartment buildings tower over the village of Kuřivody, near the airfield. Families of Soviet officers left these buildings in 1991 and they have not been utilized since due to their isolation.

The German Wehrmacht established a training area during World War II. The nearby villages of Jablonec and Svébořice have been uninhabited since 1939. While approximately 7,000 people lived in this area before World War II, today only 1,700 have remained. The hindrance to the development of the remote area of Ralsko is the lack of job opportunities. The town of Ralsko extends over an area of 170 square kilometers, which makes it the second largest urban area in the Czech Republic after Prague. But the distance between Prague and Ralsko is ninety kilometers, meaning that Ralsko is twice as far from Prague as Milovice, and there is no direct railway connection (Nováková 2011).

One important reason for Ralsko's different path of development is that this region was historically a part of the Sudetenland, and was ripped away from the rest of Czechoslovakia by the Munich agreement of 1938. After World War II its inhabitants, ethnic Germans, were expelled from Czechoslovakia. Suddenly deserted, this region was turned into a military training area, which changed its development for the next forty years and more. Such a long gap without a civilian presence is very hard to fill. The process of depopulation started in 1938 and is ongoing.

Because re-population was not an option for Ralsko, its future has been planned in terms of the local nature, which is well preserved due to this area having been in military use and closed to the public for many decades. A nature reserve for rare animals has been established in Ralsko in the territory of the former artillery range Židlov. The area of the Geopark Ralsko extends over 249 square kilometers. The main actor there is the nongovernmental organization Geopark Ralsko, which receives ample support from European funds (see the Geopark Ralsko website).

At the end of September 2016, "Sky Soldier II", a joint airborne exercise of US and Czech paratroopers, took place around the Hradčany airfield. The Czech Army leadership has announced its intention of exploring the possibility of using this area again for military purposes (Polák 2016). Whether this intention will be realized remains uncertain for now. The Czech Army got rid of many of the military training facilities during the period of geopolitical stability of the 1990s. Now, however, it seems to be necessary to improve the army's military skills. Because the Czech society has expressed little interest in Ralsko, this remote and forgotten region may well become a military zone again. 


\section{AFTER THE WITHDRAWAL}

Following the withdrawal of Soviet forces from Czechoslovakia, the Czech society adopted a negative attitude towards the new deployment of any foreign forces. Since the Czech Republic joined NATO in 1999, many short-term joint exercises have taken place in its territory. But when, in 2006, the Czech government announced its intention to allow the USA to construct an anti-missile defense system on the Czech territory, responses varied. Many were afraid that the Russian Federation would interpret the construction of an anti-missile defense system as an expression of hostility and that this could cause Russia to take dangerous action. Nevertheless, in 2008 the Minister of Defense of the Czech Republic and the Secretary of Defense of the USA signed a preliminary agreement for the construction of an anti-missile defense system. Reactions from some parts of the Czech society were openly negative, including by some anti-American groups, leftist nongovernmental organizations, environmentalists, and some political parties. According to annual reports of the Security Information Service, the Intelligence Service of the Czech Republic as well as some groups and individuals expressing discontent with the government's plan were supported by the Intelligence Service of the Russian Federation (Annual Report 2007). The most remarkable (active and aggressive) entity was a civic association called Ne Základnám! (Say no to bases!), which organized demonstrations and events. This initiative was very closely connected to the Communist Party of Czech and Moravia and to leftist NGOs. In 2009 the US administration announced that it was stepping back from its original intention to include the Czech Republic in an anti-missile defense system.

These events and reactions unfolded at a time of relative stability in Europe. At the end of March 2015, it was announced that a US Army convoy would transit the Czech territory from exercises in the Baltic states and Poland to bases in Germany. Communists and leftist organizations protested against this plan and announced that they would form blockades and demonstrations. A representative of the 'Say no to bases!' association even promised that they would use Molotov cocktails and organize violent protests (see Nová Republika). In reality, only a few protesters showed up for the actions, while thousands of people waited for the US Army convoys and spontaneously cheered the soldiers, welcoming them to the Czech Republic. This changed attitude should not be interpreted as a sign of public agreement with the prospect of deploying foreign forces or, in particular, of establishing new military bases on Czech territory. However, it does suggest that the Czech society has become more aware of security risks. 


\section{CONCLUSION}

The process of creating military bases and facilities has generally caused problems. In the Czech case, repeated experiences with foreign occupation forces have deeply influenced both the character of the landscape and the memory of its inhabitants. Towns and the environment are only very slowly being converted back into civil spaces. The speed of this process seems to depend, among other things, on the distance of former military regions from populated and cultivated areas. The history and traditions of sites during the past hundred or more years are also very important in terms of recovery. The past and present are harder to connect in places where the natural path of development has been broken for long periods. Dealing with the past in former military facilities is complex. There has not been a systematic approach to military empty areas in the Czech Republic. Approaches taken to these sites depend on local opportunities, yet what they seem to share is a reluctance or even refusal on the part of new inhabitants and local authorities to address and preserve the history of the period of Soviet military presence. Former military buildings and facilities have been reconstructed and re-utilized without references to the past. In remote localities in particular, natural resources are used to attract tourists.

I sometimes also lack the courage to look at our "inconvenient" past and to learn from it.

\section{ACKNOWLEDGEMENTS}

This article was written as part of the project "Czech society and the Soviet army 1968-1991" supported by the Grant Agency of the Czech Science Foundation (project no. 17-06744S).

\section{NOTES}

1 Socialistic Youth Union (a Czechoslovakian version of the Komsomol).

${ }^{2}$ Charter 77 initiative: a citizens' Czechoslovakian informal oppositional group established in January 1977. 


\section{REFERENCES}

Belda, Josef \& Benčík, Antonín \& Pecka, Jindřich 1994a. Dislokace sovětských vojsk $v$ Československu 1968-1969: Materiály, studie, dokumenty, č. 6. [Displacement of Soviet Troops in Czechoslovakia 1968-1969: Materials, Studies, Documents, Vol. 6.] Prague: Ústav pro soudobé dějiny Akademie věd ČR.

Belda, Josef \& Benčík, Antonín \& Pecka, Jindřich 1994b. Polsko a vojenská intervence $v$ Československu 1968. Materiály, studie, dokumenty, č. 5. [Poland and the 1968 Military Intervention in Czechoslovakia: Materials, Studies, Documents, Vol. 5.]. Prague: Ústav pro soudobé dějiny Akademie věd ČR.

Belda, Josef \& Benčík, Antonín \& Pecka, Jindřich 1995. Podíl NDR na intervenci proti Československu v roce 1968. Materiály, studie, dokumenty, č. 9. [Participation of the German Democratic Republic in the 1968 Intervention in Czechoslovakia: Materials, Studies, Documents, Vol. 9.] Prague: Ústav pro soudobé dějiny Akademie věd ČR.

Benčík, Antonín 1995. Sovětská vojska v Československu a 'mírové’ úsilí SSSR 1968-1973. Materiály, studie, dokumenty, č. 9. [Soviet Troops in Czechoslovakia and the "Peaceful" Effort of the USSR 1968-1973: Materials, Studies, Documents, Vol. 9.] Prague: Ústav pro soudobé dějiny Akademie věd ČR.

Benčík, Antonín \& Pecka, Jindřich 1994. Mad’arská účast v srpnové invazi 1968. Materiály, studie, dokumenty, č. 4. [Hungarian Participation in Invasion in August 1968: Materials, Studies, Documents, Vol. 4.] Prague: Ústav pro soudobé dějiny Akademie věd ČR.

Benčík, Antonín \& Pecka, Emanuel \& Pecka, Jindřich \& Sarandev, Atanas 1995. Bulharsko a československá krize 1968. Materiály, studie, dokumenty, č. 11. [Bulgaria and the Czechoslovak Crisis of 1968: Materials, Studies, Documents, Vol. 11.] Prague: Ústav pro soudobé dějiny Akademie věd ČR.

Benčík, Antonín \& Paulík, Jan \& Pecka, Jindřich (eds.) 1999. Vojenské otázky československé reformy 1967-1970. Díl 6/2. Srpen 1968 - květen 1971. [Military Issues of the Czechoslovak Reform of 1967-1970. Part 6/2. August 1968 - May 1971.] Prague \& Brno: Ústav pro soudobé dějiny Akademie věd ČR a Doplněk.

Blahová, Veronika 2016. Historie bývalého vojenského prostoru Milovice a památek $v$ okolnich obcich. [The History of the Former Military Area Milovice and Monuments in Surrounding Villages.] Bachelor thesis. University of Hradec Králové. Available at https://theses.cz/vyhledavani/?search=The+history+of+th e+former+military+area+Milovice+and+monuments+in+surrounding+villages, last accessed on September 1, 2017.

Blažek, Petr \& Eichler, Patrik \& Jareš, Jakub \& Benešová, Michala \& Cílek, Václav \& Halík, Tomáš \& Hejdánek, Ladislav \& Chalupecký, Jindřich \& Jáchimová, Veronika \& Kamiński, Łukasz \& Kranát, Jan \& Kolář, Jan \& Lederer, Jiří \& Nachmilnerová, Eva \& Petrusek, Miloslav \& Putna, Martin C. \& Trojan, Jakub S. \& Vilímek, Tomáš \& Yannakakis, Ilios 2009. Jan Palach ‘69. Prague: Filozofická fakulta UK v Praze. 
Czerwinski, Edward J. \& Piekalkiewicz, Jarosław 1972. The Soviet Invasion of Czechoslovakia: Its Effects on Eastern Europe. New York: Praeger Publishers.

Eidlin, Fred H. 1980. The Logic of 'Normalization': The Soviet Intervention in Czechoslovakia of 21 August 1968 and the Czechoslovak Response. New York: Columbia University Press.

Felcman, Ondřej 1995. Invaze a okupace: K úloze SSSR a sovětských vojsk ve vývoji Československa v letech 1968-1991. Pobyt sovětských vojsk na území Československa 1968-1991. Materiály, studie, dokumenty, č. 15. [Invasion and Occupation: Role of the USSR and Soviet Troops in the Development of Czechoslovakia in 1968-1971. Deployment of Soviet Troops in the Czechoslovak Territory 1968-1991: Materials, Studies, Documents, Vol. 15.] Prague: Ústav pro soudobé dějiny Akademie věd ČR.

Felcman, Ondřej \& Volková, Květoslava 1994. Co stála srpnová invaze. Pobyt sovětských vojsk na území Československa 1968-1991. Materiály, studie, dokumenty, č. 3. [What Was the Cost of the August Invasion? Deployment of Soviet Troops in the Czechoslovak Territory 1968-1991: Materials, Studies, Documents, Vol. 3.] Prague: Ústav pro soudobé dějiny Akademie věd ČR.

Horák, Zdeněk 2016. Sovětská posádka ve Vysokém Mýtě 1968-1990. [The Soviet Military Presence in Vysoké Mýto 1968 to 1990.] Unpublished MA thesis. University of Hradec Králové. Available at http://theses.cz/id/vceqhi/, last accessed on September 1, 2017.

Hradecká, Vladimíra \& Koudelka, František 1998. Kádrová politika a nomenklatura KSC 1969-1974. [Cadre Politics and Nomenclature of the Communist Party of Czechoslovakia in 1969-1974.] Prague: Ústav pro soudobé dějiny Akademie věd ČR.

Hubený, David 2013. Spolupráce Policejního ředitelství a Rudé armády na zajištění bezpečnosti ve Velké Praze a potlačení kriminality rudoarmejců. [Cooperation of the Police Directorate and Red Army to Guarantee Security in the Greater Prague and Suppress Red Army Criminality.] Sborník archivu bezpečnostních složek, Vol. 11, pp. 159-174.

Macek, Jozef et al. (comps.) 1990 [1968]. Sedm pražských dnů: 21.-27. srpen 1968. Dokumentace. [Seven Days in Prague: August 21-27, 1968. Documentation.] Prague: Academia.

Nad'ovič, Svetozár \& Foertsch, Hartmut \& Karácsony, Imre \& Ostrowski, Zdzisław 2005. The Great Withdrawal: Withdrawal of the Soviet - Russian Army from Central Europe 1990-1994. Bratislava: Ministry of Defense of the Slovak Republic.

Nováková, Klára 2011. Vojenský újezd Ralsko v letech 1950-1968. [Military Area Ralsko in 1950-1968.] Bachelor thesis. Univerzita Karlova. Available at https://is.cuni. cz/webapps/zzp/detail/87257/, last accessed on September 1, 2017.

Pecka, Jindřich 1996a. Odsun sovětských vojsk z Československa 1989-1991: Dokumenty. [Transfer of Soviet Forces from Czechoslovakia 1989-1991: Documents.] Prague: Ústav pro soudobé dějiny Akademie věd ČR.

Pecka, Jindřich 1996b. Sovětská armáda v Československu 1968-1991: Chronologický prehled. [Soviet Army in Czechoslovakia 1968-1991: Chronological Overview.] Prague: Ústav pro soudobé dějiny Akademie věd ČR. 
Polák, Michael 2016. Vojáci v Ralsku po 25 letech: Čeští a američtí výsadkáři tam budou mít rozsáhlé cvičení. [Soldiers in Ralsko after 25 Years: Czech and American Paratroopers Will Have Extensive Training.] Novinky.cz, September 19. Available at https://www.novinky.cz/domaci/414822-vojaci-v-ralsku-po-25-letechcesti-a-americti-vysadkari-tam-budou-mit-rozsahle-cviceni.html, last accessed on September 1, 2017.

Pohunek, Jan 2015. Odraz archeologizovaných krajinných prvki̊ v etnografických pramenech. [Reflection of Archaeologized Landscape Elements in Ethnographic Resources.] Diss. (PhD Thesis). Univerzita Karlova. Available at http://www. academia.edu/31086650/Odraz_archeologizovan\%C3\%BDch_krajinn\%C3\%BDch_ prvk\%C5\%AF_v_etnografick\%C3\%BDch_pramenech, last accessed on September 1, 2017.

Povolný, Daniel 2010. Vojenské řešení Pražského jara 1968, II. [Military Solution of the Prague Spring of 1968, Part II.] Prague: Ministerstvo obrany ČR. Available at http://www.mocr.army.cz/assets/multimedia-a-knihovna/publikace/vojenskahistorie/21-prazske-jaro_iidil_internet.pdf, last accessed on September 1, 2017.

Řehounek, Jan 2013. Osudové okamžiky: Sto let vojenského výcvikového prostoru MiloviceMladá. [Fateful Moments: A Hundred Years of Milovice-Mladá Training Ground.] Nymburk: Kaplanka pro Svazek obcí Svatojiřský les.

Skilling, Harold Gordon 1976. Czechoslovakia's Interrupted Revolution. Princeton: Princeton University Press.

Tomek, Prokop \& Pejčoch, Ivo 2015. Černá kniha sovětské okupace: Sovětská armada $v$ Československu a její oběti 1968-1991. [Black Book of Soviet Occupation: Soviet Army in Czechoslovakia and Its Victims 1968-1991.] Cheb: Svět křídel.

Tomek, Prokop 2016. Jiný pohled: Zpráva přidělenců obrany velvyslanectví Spojeného království v Praze za rok 1981. [A View from the Other Side: 1981 Report by the Military Attaché of the British Embassy in Prague.] Historie a vojenství, Vol. 65, No. 2, pp. 60-72.

Tůma, Oldřich \& Jaroš, Oldřich \& Koudelka, František \& Nosková, Alena 1996. Srpen '69: edice dokumentů. [August 1969: Issue of Documents.] Prague: Maxdorf.

\section{INTERNET SOURCES}

Annual Report 2007 = Annual Report of the Security Information Service for 2007. Available at https://www.bis.cz/vyrocni-zprava5819.html?ArticleID=30; https://www.bis. cz/vyrocni-zprava2645.html?ArticleID=29, last accessed on September 1, 2017.

Česká krajina. Available at http://www.ceska-krajina.cz/, last accessed on August 31, 2017.

Geopark Ralsko. Available at http://geoparkralsko.cz/en, last accessed on September 1, 2017.

Město Milovice $=$ Základní informace o městě. [Basic Information about the City.] Available at http://urad.mesto-milovice.cz/cs/samosprava/zakladni-informace-omeste.html, last accessed on August 31, 2017. 
Milovice. Available at http://volnycas.mesto-milovice.cz/cs/pamatky-a-prirodni-zajimavosti/ zanikla-obec-mlada.html, last accessed on August 31, 2017.

Mladá Boleslav = Stopy po působení sovětských vojsk jsou mnohde patrné dosud. [Traces of Soviet Troops Are Still Visible.] Available at http://www.mb-net.cz/stopy-popusobeni-sovetskych-vojsk-jsou-mnohde-patrne-dosud/d-10749, last accessed on August 31, 2017.

Ne Základnám. [Say No to Bases!] Available at http://nezakladnam.cz/ens, last accessed on September 1, 2017.

Nová Republika. Available at http://www.novarepublika.cz/2015/03/molotovovymikoktejly-proti-americke.html, last accessed on September 1, 2017. 